\title{
EXTRACTION SILICA FROM RICE HUSK WITH NaOH LEACHING AGENT WITH TEMPERATURE VARIATION BURNING RICE HUSK
}

\author{
Amru Daulay $^{1}$, Andriayani ${ }^{2,}{ }^{凶}$, Marpongahtun $^{2}$ and Saharman Gea ${ }^{2}$ \\ ${ }^{1}$ Postgraduate School, Department of Chemistry, Faculty of Mathematics and Natural Sciences, \\ Universitas Sumatera Utara, J1 Bioteknologi No.1, Medan, 20155, Indonesia \\ ${ }^{2}$ Department of Chemistry, Faculty of Mathematics and Natural Sciences, Universitas Sumatera \\ Utara, Jl. Bioteknologi No.1 Medan, 20155, Indonesia \\ ${ }^{\circledR}$ Corresponding Author: andriayani@usu.ac.id
}

\begin{abstract}
Silica can obtain by utilizing rice husk $(\mathrm{RH})$. This study uses $\mathrm{NaOH}$ leaching agents with temperature variations of $600,700,800,900^{\circ} \mathrm{C}$ at burning $\mathrm{RH}$. Rice husk ash (RHA) reacted with $\mathrm{NaOH} 10 \%$ at $90^{\circ} \mathrm{C}$ at $240 \mathrm{rpm}$ for $2 \mathrm{~h}$, then the addition of $\mathrm{HCl}$ until $\mathrm{pH} 7$ and drying to become $\mathrm{SiO}_{2}$. Extracted silica characterization using FTIR showed silanol and siloxy groups, XRD showed that silica dominates by quartz and calcite, XRF showed components of $\mathrm{SiO}_{2}$ and $\mathrm{Si}$. Variation temperatures of $600,700,800,900^{\circ} \mathrm{C}$ at burning $\mathrm{RH}$ made different components $\mathrm{SiO}_{2}$ and $\mathrm{Si}$.
\end{abstract}

Keywords: Rice Husk, Silica, Leaching, $\mathrm{NaOH}$, Si.

RASĀYAN J. Chem., Vol. 14, No.3, 2021

\section{INTRODUCTION}

$\mathrm{RH}$ is a byproduct of rice processing that accounts for roughly $20 \%$ of the bulk grain weight. ${ }^{1} \mathrm{RH}$ components include $70-80 \%$ organic elements such as lignin, cellulose, and others. Mineral components such as silica, alkalis, and trace elements make up the remaining $20-30 \%{ }^{2} \mathrm{RH}$ has high silica content. Silica extract from $\mathrm{RH}$ in a simple method like liquid extraction as $\mathrm{NaOH}$ leaching agent. ${ }^{3}$ The burning process controlled at high temperatures will produce $\mathrm{RH}$ rich in silica content for various chemical processes. Silica or silicon dioxide compound $\left(\mathrm{SiO}_{2}\right)$ use as an adsorbent, desiccant, filter media, and catalyst compound. Silica was the primary raw material in the glass industry, ceramic, refractory industry, and raw materials for silicate solutions, silicon, and alloy. ${ }^{4}$ The resulting silica of the $\mathrm{RH}$ has several advantages compared to silica minerals. Silica from RH has many refined grains, is reactive, is obtained quickly at a relatively cheap cost. Furthermore, it is supported abundant raw materials that can be updated. ${ }^{5}$

RHA has the function of binding heavy metals and can loosen the soil, making it easier for plant roots to absorb nutrients. ${ }^{6}$ RHA is a pozzolanic (pozzolanic) material which contains silica and alumina compounds. ${ }^{7}$ The utilization of RHA as pozzolanic material in cement provides several benefits, including increased strength, durability, reduced cost, and use of waste to reduce carbon dioxide emissions. In addition, RHA was a substitute material in the manufacture of refractories, ceramics, and insulating material. ${ }^{8}$ Silica obtained from plant, coal ash, and geothermal mud is amorphous and more reactive due to hydroxyl groups (silanol, Si-OH). ${ }^{9}$ Pre-treatment techniques of biomass using the oven heating method, soaking and washing using warm water, ${ }^{10}$ alkaline metal hydroxides solutions such as $\mathrm{NaOH}^{11}$ and $\mathrm{KOH},{ }^{12}$ acid solution, ${ }^{13}$ and ionic solvent. ${ }^{14}$ This study uses $\mathrm{NaOH}$ leaching agents to obtain silica. This method breaks the chemical bonds in $\mathrm{RH}$ using $\mathrm{NaOH}$ and then binds silicon with oxygen to obtain $\mathrm{SiO}_{2} .{ }^{15}$

\section{EXPERIMENTAL}

This study uses $\mathrm{NaOH}$ leaching agents with temperature variations of $600,700,800,900^{\circ} \mathrm{C}$ at burning $\mathrm{RH}$. The initial content of RH from Deli Serdang, Sumatra Utara. RH burned at the furnace with temperature variations of $600,700,800,900^{\circ} \mathrm{C}$. RH was stirred and heated with $10 \% \mathrm{NaOH}$ at $90^{\circ} \mathrm{C}, 240 \mathrm{rpm}$ for $3 \mathrm{~h}$. The filter rinses with $100 \mathrm{~mL}$ of distilled water after using Whatman filter No. 41. To make a gel, filter the 
RASĀYAN J. Chem.

Vol. 14 | No. 3 |2125-2128| July - September | 2021

(sodium silicate) and add 37\% $\mathrm{HCl}(\mathrm{pH} 7$ ). For $24 \mathrm{~h}$, the gel will store. Using distilled water, filter and rinse silica gel to create silica powder. Silica gel dried at $150^{\circ} \mathrm{C}$ for $2 \mathrm{~h}$. Characterization of the silica powder using FTIR, XRD, XRF.

\section{RESULTS AND DISCUSSION}

$\mathrm{RH}$ heated with temperature variations $600,700,800$, and $900^{\circ} \mathrm{C}$ in a furnace. RHA decreased weight after the furnace. Silica powder produced by RHA at burning RH variation temperatures of 600,700 , and $800^{\circ} \mathrm{C}$ did not significantly differ. However, at $900^{\circ} \mathrm{C}$, there was a significant decrease in Silica powder because $10 \% \mathrm{NaOH}$ at burning $\mathrm{RH}$ temperature $900^{\circ} \mathrm{C}$ could not bind silica ${ }^{16}$, as shown in Fig. -1 .

RHA was extracted used leaching with $\mathrm{NaOH} 10 \%$ to obtain $\mathrm{SiO}_{2}$, then stirring at temperature $90^{\circ} \mathrm{C}$ with $240 \mathrm{rpm}$ for $3 \mathrm{~h}$. Silica compounds dissolve quickly in alkaline solutions and precipitate into acidic solutions. Heating will speed up the reaction rate, and stirring will speed up the contact between the solute and solvent and reduce. ${ }^{17}$

Sodium Hydroxide $(\mathrm{NaOH})$ completely dissociated and formed sodium $\left(\mathrm{Na}^{+}\right)$ion and hydroxide $\left(\mathrm{OH}^{-}\right)$ion. $\mathrm{OH}^{-}$was nucleophile would be attacked $\mathrm{Si}$ on $\mathrm{SiO}_{2}{ }^{18}$ Electronegative $\mathrm{O}$ atom broke double size and obtained $\mathrm{SiO}_{2} \mathrm{OH}^{-}$then releases $\mathrm{H}^{+}$ion. Atom $\mathrm{O}$, the double bond broke again and obtained $\mathrm{SiO}_{3}{ }^{2-}$ which then dehydrogenation of $\mathrm{OH}$ binds to $\mathrm{H}^{+}$ion and includes water molecules $\left(\mathrm{H}_{2} \mathrm{O}\right)$. The negatively charged $\mathrm{SiO}_{3}{ }^{2-}$ molecule would bind to two $\mathrm{Na}^{+}$ions and form sodium silicate $\left(\mathrm{Na}_{2} \mathrm{SiO}_{3}\right)$. To separate the filtrate and the residue, sodium silicate $\left(\mathrm{Na}_{2} \mathrm{SiO}_{3}\right)$ was filtered. The $\mathrm{Na}_{2} \mathrm{SiO}_{3}$ was mixed with $37 \% \mathrm{HCl}$ to create a gel group for $24 \mathrm{~h}$.

As a precipitating agent, $\mathrm{HCl}$ is using. When $\mathrm{HCl}$ was adding, the ion exchange between $\mathrm{Na}^{+}$and $\mathrm{H}^{+}$, resulting in the formation of silicic acid. Add $\mathrm{HCl}$ to a $\mathrm{pH} 7$ because if $\mathrm{pH}$ is less than 7, the precipitate formed will dissolve again. It is because the addition of $\mathrm{HCl}$ uses to reacted with $\mathrm{NaCl}$. There is little exchange of $\mathrm{Na}^{+}$and $\mathrm{H}^{+}$ions. At $\mathrm{pH}$ 7, silica that has been precipitated and is insoluble expect to remain silica. Because of $\mathrm{HCl}$ addition to the precursor, siloxy ( $\mathrm{Si}-\mathrm{O}-)$ protonate to silanol ( $\mathrm{Si}-\mathrm{OH})$. The addition of $\mathrm{HCl}$ resulted in a significant concentration of protons $\left(\mathrm{H}^{+}\right)$in the $\mathrm{Na}_{2} \mathrm{SiO}_{3}$ and the formation of silanol groups from multiple siloxy groups ( $\mathrm{Si}-\mathrm{O})$. With $\mathrm{HCl}$ as a catalyst, the silanol group will attack by siloxy group (O-Si-O-) to create a siloxane bond (Si-O-Si). A Whatman No. 41 filters filter the precipitate, which has a small pore size that prevents the sediment from passing through. Because of the excess acid, the precipitated silica was washed and heated at $150^{\circ} \mathrm{C}$ for $2 \mathrm{~h}$ to remove the $\mathrm{Cl}^{-}$ion. As a result of the heating, the silica gel transforms into $\mathrm{SiO}_{2}$ powder. ${ }^{19}$ Table-1 shows the FTIR analysis of the functional group.

Table-1: FTIR of Silica with Temperature Variation at Burning RH

\begin{tabular}{c|c|c|c|c|c}
\hline $\begin{array}{c}\text { Temperature } \\
\text { variation at Burning } \\
\mathrm{RH}\left({ }^{\circ} \mathrm{C}\right)\end{array}$ & $\begin{array}{c}\text { OH stretching } \\
\left(\mathrm{cm}^{-1}\right)\end{array}$ & $\begin{array}{c}\text { OH bending } \\
\left(\mathrm{cm}^{-1}\right)\end{array}$ & $\begin{array}{c}\text { Si-O-Si- } \\
\left(\mathrm{cm}^{-1}\right)\end{array}$ & $\begin{array}{c}\text { Si-OH bending } \\
\left(\mathrm{cm}^{-1}\right)\end{array}$ & $\begin{array}{c}\text { Si-O- } \\
\left(\mathrm{cm}^{-1}\right)\end{array}$ \\
\hline 600 & 3404.23 & 1637.07 & 1061.67 & 795.93 & 445.51 \\
\hline 700 & 3398.28 & 1458.39 & 1042.51 & 798.70 & 447.03 \\
\hline 800 & 3398.28 & 1637.09 & 1062.28 & 795.56 & 448.66 \\
\hline 900 & 3398.28 & 1637.07 & 1065.57 & 796.41 & 448.66 \\
\hline
\end{tabular}

Results XRD of silica showed that the crystal area (peak) was quartz and calcite. The search-match RHA data showed that the peak that appears is quartz dominant at an angle (20): 5-90. There are two identified phases namely quartz, and calcite. XRD patterns of silica with $\mathrm{NaOH} 10 \%$ formed crystalline peaks in the quartz phase in the amorphous phase $\mathrm{e}^{20}$. The diffraction pattern showed a shift in the top position. It is possible because $\mathrm{SiO}_{2}$ begins to form at $\mathrm{pH}$ 7. Still, many impurities may reduce. $\mathrm{NaOH}$ also plays a significant role in forming sodium silicate $\left(\mathrm{Na}_{2} \mathrm{SiO}_{3}\right)$ to produce $\mathrm{SiO}_{2}$. Not all $\mathrm{SiO}_{2}$ reacted with $\mathrm{NaOH}$ to form $\mathrm{Na}_{2} \mathrm{SiO}_{3}$ made to shift, as shown in Fig.-2.

Table-2 showed the XRF of silica variation temperature RHA. It showed the highest percentage of $\mathrm{SiO}_{2}$ and $\mathrm{Si}$ components with variation temperature that showed $\mathrm{SiO}_{2}$ and $\mathrm{Si}$ highest percentage from RHA at temperature $600^{\circ} \mathrm{C}$. 
RASĀYAN J. Chem.

Vol. 14 | No. 3 |2125-2128| July - September | 2021

Table-2. XRF of component $\mathrm{SiO}_{2}$ dan $\mathrm{Si}$ variation temperature at Burning $\mathrm{RH}$

\begin{tabular}{c|c|c}
\hline Temperature at Burning $\mathrm{RH}\left({ }^{\circ} \mathrm{C}\right)$ & Component $\mathrm{SiO}_{2}(\%)$ & Component $\mathrm{Si}(\%)$ \\
\hline 600 & 44.4 & 24.3 \\
\hline 700 & 31.8 & 16.3 \\
\hline 800 & 43.8 & 23.9 \\
\hline 900 & 39.5 & 20.3 \\
\hline
\end{tabular}

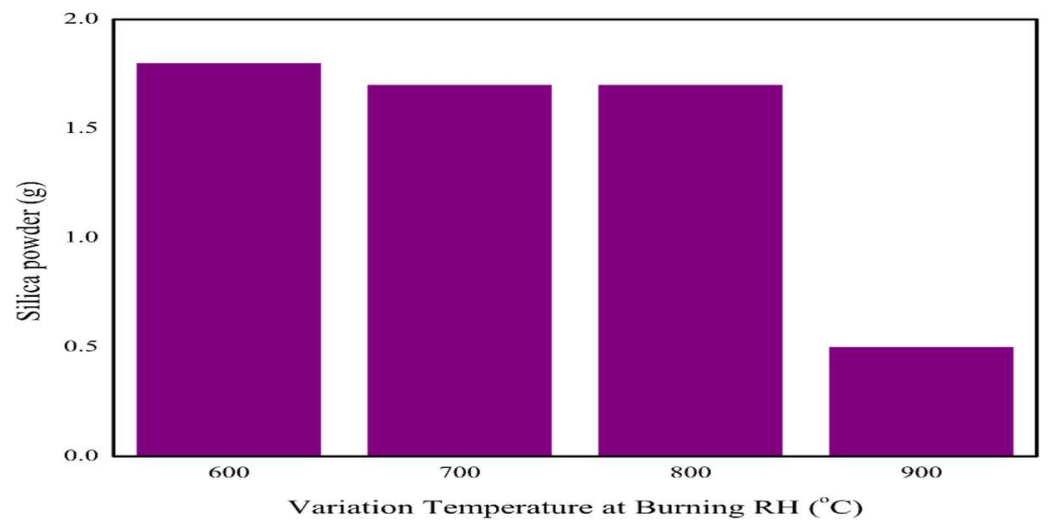

Fig.-1: Weight of Silica Powder with Variation Temperature at Burning RHA

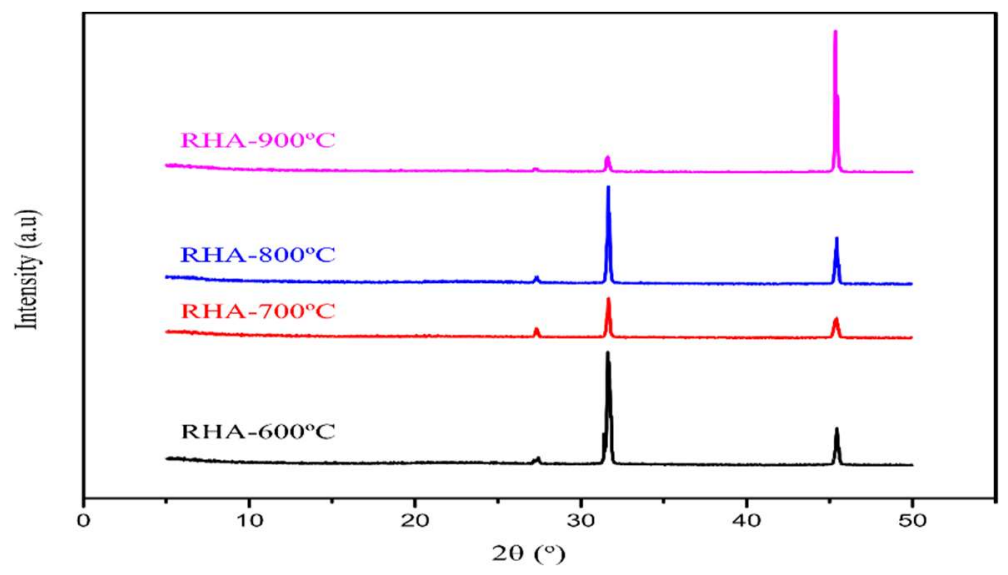

Fig.-2: XRD Patterns of Silica with Variation Temperature RHA

\section{CONCLUSION}

The burning of $\mathrm{RH}$ with variation temperatures gives different components $\mathrm{SiO}_{2}$ and $\mathrm{Si}$. From burning $\mathrm{RH}$ variation temperatures $600,700,800,900^{\circ} \mathrm{C}$ represented highest $\mathrm{SiO}_{2}$ and $\mathrm{Si}$ at $600^{\circ} \mathrm{C} \mathrm{RHA}$ with $\mathrm{SiO}_{2}$ $(44.4 \%)$ and $\mathrm{Si}(24.3 \%)$.

\section{ACKNOWLEDGMENT}

This research was funding "Penelitian Disertasi Doktor (PDD) Dikti 2020" with contract number 11/AMD/E1/KP.PTNBH/2020.

\section{REFERENCES}

1. B. A. Tayeh, R. Alyousef, H. Alabduljabbar, A. Alaskar, Journal of Cleaner Production, 312, 127734(2021), https://doi.org/10.1016/j.jclepro.2021.127734

2. N. Setyawan, Hoerudin, A. Wulanawati, IOP Conference Series: Earth and Environmental Science, 309, (2019), https://doi.org/10.1088/1755-1315/309/1/012032

3. A. Saludung, T. Azeyanagi, Y. Ogawa, K. Kawai, Journal of Cleaner Production, 315, 128210(2021), https://doi.org/10.1016/j.jclepro.2021.128210

4. A. Andriayani, S. L. Raja, H. Sihotang, N. Sofyan, International Journal of Technology, 6(7), 1174(2015), https://doi.org/10.14716/ijtech.v6i7.1493 
RASĀYAN J. Chem.

Vol. 14 | No. 3 |2125-2128| July - September | 2021

5. A. Andriayani, S. B. Sembiring, N. Aksara, N. Sofyan, Advanced Materials Research, 789, 124(2013), https://doi.org/10.4028/www.scientific.net/AMR.789.124

6. P. Mathur, S. Roy, Plant Physiology and Biochemistry, 157, 114(2020), https://doi.org/10.1016/j.plaphy.2020.10.011

7. M. I. AlBiajawi, R. Embong, K. Muthusamy, Materials Today: Proceedings, (2021), https://doi.org/10.1016/j.matpr.2021.02.260

8. D. K. Panesar, Developments in the Formulation and Reinforcement of Concrete, Elsevier Ltd, p.55 (2019), https://doi.org/10.1016/B978-0-08-102616-8.00003-4

9. N. El-Gazzar, T. N. Almanaa, R. M. Reda, M. N. El Gaafary, A. A. Rashwan, F. Mahsoub, Saudi Journal of Biological Sciences, 28(9), 5119(2021), https://doi.org/10.1016/j.sjbs.2021.05.027

10. S. Muthukrishnan, S. Gupta, H. W. Kua, Theoretical and Applied Fracture Mechanics, 104, 102376(2019), https://doi.org/10.1016/j.tafmec.2019.102376

11. E. Kamseu, L. M. Beleuk à Moungam, M. Cannio, N. Billong, D. Chaysuwan, U. C. Melo, C. Leonelli, Journal of Cleaner Production, 142, 3050(2017), https://doi.org/10.1016/j.jclepro.2016.10.164

12. B. A. Goodman, Journal of Bioresources and Bioproducts, 5(3), 143(2020), https://doi.org/10.1016/j.jobab.2020.07.001

13. I. J. Fernandes, D. Calheiro, F. A. L. Sánchez, A. L. D. Camacho, T. L. A. De Campos Rocha, C. A. M. Moraes, V. C. De Sousa, Materials Research, 20, 512(2017), https://doi.org/10.1590/1980-5373mr-2016-1043

14. A. Stein, B. J. Melde, R. C. Schroden, Advanced Materials, 12(9), 1403(2000), https://doi.org/10.1002/1521-4095(200010)12:19<1403::AID-ADMA1403>3.0.CO;2-X

15. S. Steven, E. Restiawaty, P. Pasymi, Y. Bindar, Journal of the Taiwan Institute of Chemical Engineers, 122, 51(2021), https://doi.org/10.1016/j.jtice.2021.04.053

16. V. T. A. Van, C. Rößler, D. D. Bui, H. M. Ludwig, Construction and Building Materials, 43, 208(2013), https://doi.org/10.1016/j.conbuildmat.2013.02.004

17. E. P. Ayswarya, A. B. Nair, E. T. Thachil, Materials Today: Proceedings, (2021), https://doi.org/10.1016/j.matpr.2021.06.067

18. M. Spennato, A. Todea, L. Corici, F. Asaro, N. Cefarin, G. Savonitto, C. Deganutti, L. Gardossi, EFB Bioeconomy Journal, 1, 100008(2021), https://doi.org/10.1016/j.bioeco.2021.100008

19. S. N. Ishmah, M. D. Permana, M.L. Firdaus, D. R. Eddy, PENDIPA Journal of Science Education, 4(2), 1(2020), https://doi.org/10.33369/pendipa.4.2.1-5

20. R. K. Biswas, P. Khan, S. Mukherjee, A. K. Mukhopadhyay, J. Ghosh, K. Muraleedharan, Journal of Non-Crystalline Solids, 488, 1(2018), https://doi.org/10.1016/j.jnoncrysol.2018.02.037

[RJC-6351/2021] 